\title{
International Journal of Business and Technology
}

Volume 6

Issue 1 Fall 2017

Article 1

November 2017

\section{The right to use the Albanian language as an official language in Macedonia: the new draft law, its content, advancement and comparison}

Bekim Kadriu

University of Tetova, bekim.kadriu@unite.edu.mk

Ylber Sela

University of Tetova, ylber.sela@unite.edu.mk

Follow this and additional works at: https://knowledgecenter.ubt-uni.net/ijbte

Part of the Law Commons

\section{Recommended Citation}

Kadriu, Bekim and Sela, Ylber (2017) "The right to use the Albanian language as an official language in Macedonia: the new draft law, its content, advancement and comparison," International Journal of Business and Technology: Vol. 6 : Iss. 1, Article 1.

DOI: $10.33107 /$ ijbte.2017.6.1.01

Available at: https://knowledgecenter.ubt-uni.net/ijbte/vol6/iss1/1

This Article is brought to you for free and open access by the Publication and Journals at UBT Knowledge Center. It has been accepted for inclusion in International Journal of Business and Technology by an authorized editor of UBT Knowledge Center. For more information, please contact knowledge.center@ubt-uni.net. 


\title{
The right to use the Albanian language as an official language in Macedonia: the new draft law, its content, advancement and comparison
}

\author{
Bekim Kadriu ${ }^{1}$, Ylber Sela ${ }^{2}$ \\ ${ }^{1,2}$ University of Tetova, Faculty of Law \\ Str. Ilinden, nn, Tetova, Macedonia \\ \{bekim.kadriu ${ }^{1}$, ylber.sela $\left.{ }^{2}\right\} @$ unite.edu.mk
}

\begin{abstract}
The use of Albanian language as official language in Macedonia has been a challenge especially after the Ohrid Framework Agreement (OFA) in 2001. Before 2001, Albanian language was defined as an official language and was used only in private matters as well in primary and secondary education. With the OFA and Constitutional changes in 2002, the language that is spoken by $20 \%$ of the population in the country was defined as an official language, but it's application in practice was left to be regulated by e specific law. The law was adopted in 2008, 6 years after the constitutional changes.

Now there is a new law proposed, which is supposed to regulate in more efficient way the use of Albanian language as official language in Macedonia. With this paper, the authors are trying to answer some legal questions that has been debated in the country: firstly, is Albanian language official language and whether it is of a same level of application as Macedonian language; secondly, what are the novelties of the new draft law, and how the use of Albanian language is improved and advanced; thirdly, what are the practical challenges for the implementation of the new draft law. The authors of the paper will refer to international standards on use of languages as well as to relevant national legislation, as a tool to compare the new draft law in Macedonia.
\end{abstract}

Keywords: human rights, use of language, Albanian language

\section{Introduction}

The right of use of the native language is a basic human right, as such guaranteed by international human rights instruments. These instruments guarantee to individuals, mainly persons belonging to minorities, the righttouse theirlanguage in private and in public sphere.

The use of language in international law as a human right is mostly related to minorities, since the official language of the state reflects the use of majority language(in the administration, schools, courts, etc.). Thus, the use of majority language is not necessary to be guaranteed as a special right. Contrary, human rights instrument guarantee the use only of minority language, in private and public sphere.

The international human rights instruments create a minimum standard for the use of minority languages, mostly in the private sphere, but also in education, media, contact with administration etc. But these are minimum standards, which allow the states to go beyond what is required by the 
said instruments. This is the point where we start, namely the use of Albanian language in Macedonia goes beyond what is required by human rights instruments and these instruments cannot be seen as a standard applicable to the use of Albanian language in Macedonia. As a minimum standard yes, but not as an obstacle Albanian language to be used as on official language in Macedonia, broader that the international standards prescribe. And that is well known principle in international human rights law. ${ }^{1}$

\section{International human rights standards on the use of languages}

As it was mentioned in the introduction, the use of minority language is guaranteed ininternational human rights instruments. However, international instruments that provide the use of language, set a minimum standard and often are very soft.

\section{UN declaration on the Rights of Persons Belonging to National or Ethnic, Religious or Linguistic Minorities}

We will mention firstly the United Nations Declaration on the Rights of persons belonging to National or Ethnic, Religious or Linguistic Minorities. ${ }^{2}$ First of all, this instrument is a declaration, and as such not legally binding upon states. It is part of the so called soft law. ${ }^{3}$ Secondly, regarding the use of language, the Declaration suggests states to take "appropriate" measures, "wherever possible", "persons belonging to minorities may have adequate opportunities to learn their mother tongue or to have instruction in their mother tongue". ${ }^{4}$ And in it's Article 2 the Declaration grants to persons belonging to minorities the right to use their own language, in private and public.

With these two provisions only, the declaration doesn't really establish certain standard on the use of languages. Even its wording is very soft and gives states wide margin of discretion. This is seen from the phrase "wherever possible", which always will be a matter of state discretion. But also, the Declaration does not precisely stipulate in what extent the minority language can be used, whether members of minorities can address institutions in their own language, or the public bodies and institutions can use the minority language as official one. Again, this is left to the discretion of the state. This is why we hold that these are minimum standard, but cannot be seen as obstacle states to prescribe broader use of minority or regional languages within their territories.

1 One of the most important human rights instrument, The Framework Convention on the Protection of National Minorities (see infra foot note 5), in its Article 22 stipulates expressly that nothing in the Convention "shall be construed as limiting or derogating from any of the human rights and fundamental freedoms which may be ensured under the laws of any Contracting Party or under any other agreement to which it is a Party". Similar clause has the European Charter for Regional and Minority Languages, infra foot note 134 and the accompanying text.

2 The Declaration on the Rights of Persons belonging to National or Ethnic, Religious and Linguistic Minorities was adopted by the UN General Assembly Resolution 47/135 of 18 December 1992.

3 This is understandable if we bear in mind the fact that is adopted under the United Nations umbrella, where the fight for minority rights is very hard, compere to smaller in number organizations, such as the Council of Europe.

${ }^{4}$ The Declaration on the Rights of Persons belonging to National or Ethnic, Religious and Linguistic Minorities, Article 3, paragraph 3. 


\section{Framework Convention on the Protection of National Minorities}

The second relevant instrument is the Framework Convention on the protection of National Minorities [hereinafter "the Framework Convention]. ${ }^{5}$ This instrument is a treaty adopted within the Council of Europe and ratified by 39 member states, including Macedonia. ${ }^{6}$ Differently from the Declaration, it is legally binding instrument. Generally speaking, the Framework Convention also stipulates soft obligations on state parties.

First of all, the Framework Convention stipulates that "states should" take appropriate measures so that "wherever possible", persons belonging to minorities may "have adequate opportunities to learn their mother tongue or to have instruction in their mother tongue". ${ }^{7}$ So, even for the right members of minorities to learn their mother tongue, the Framework Convention leaves it to the discretion of the state, to see if that is "whether possible".

As for the communication between the persons belonging to minorities and administrative authorities, the Framework Convention requires many conditions. Firstly, the areas should be inhabited by persons belonging to national minorities traditionally or in substantial number (which also is a matter of interpretation); secondly, the persons should require and the requests should correspond to a real need (which gives the states a wide discretionper se); thirdly, the wording "the states shall endeavor to ensure as far as possible" also leaves wide discretion to the state to decide whether they can achieve to guarantee such communication in the minority language between the members of minorities and administrative authorities. ${ }^{8}$

Regarding the right to education, the Framework Convention obliges the state parties to recognize the right of members of minorities to learn their minority language, but regarding instruction in such a language, it also requires some conditions, such as: first, the areas should be inhabited traditionally or in substantial numbers by persons belonging to national minorities; second, the state parties shall endeavor to ensure, as far as possible, that members of minorities to be taught or to receive instruction in their language. With this wording, the Framework Convention leaves a great discretion to the state parties to decide whether to allow within their educational systems, instructions in the native language of the members of minorities. ${ }^{9}$ Also, the Framework Convention does not specify in what levels these instructions will be given, whether in primary, secondary or higher education. This also shows the intent of the drafters of the Convention to allow state parties a broad discretion on the matters of use of minority languages.

The Framework Convention obliges states parties to recognize members belonging to minorities their right to use their name and surname in the minority language and official recognition to them; the right to display signs, inscriptions and other information of private nature visible to the public in the minority language; and to display traditional local names, street names and other topographical

${ }^{5}$ Framework Convention for the Protection of National Minorities, Strasbourg, 1/2/1995, ETS 157.

${ }^{6}$ For the number of ratification, see the official web site of Council of Europe http://www.coe.int/en/web/conventions/full-list/-

/conventions/treaty/157/signatures? $\mathrm{p}$ auth $=\mathrm{vNvquAdG}$. Macedonia has ratified the Framework Convention in 1997 [last visited 04 October 2017]

${ }^{7}$ Framework Convention for the Protection of National Minorities, Article 10.

${ }^{8}$ Framework Convention for the Protection of National Minorities, Article 10, paragraph 2.

${ }^{9}$ Framework Convention for the Protection of National Minorities, Article 14. 
indications intended to the public in the minority language, if areas are traditionally inhabited by substantial number of persons belonging to minorities, if there is a sufficient demand for this and allows the state parties to endeavor to do such a thing.

Again, as a conclusion for this part, the Framework Convention does not establish precise level of the use of minority languages, especially not in the public. The Framework Convention does not precisely stipulate when members of minorities can use their own language in the public institutions; can they address public institutions on central or local level in their own language; will the public institution answer in the language of minorities; can judicial and other proceedings be held in the minority language; in what educational level can minorities use their own language; lastly, the wording of the Framework Convention is very soft and allows states wide discretion to decide how far will go in guaranteeing the use of minority language, especially in the public sphere.

\section{European Charter for Regional or Minority Languages}

The European Charter for Regional and Minority Languages ${ }^{10}$ [hereinafter "the Charter"] is a treaty, similar to the Framework Convention and is also adopted within the Council of Europe. With status of October 2017, it has 25 ratifications. Macedonia has signed the Charter in 1996, but it has not ratified it, even 21 years after its signing. ${ }^{11}$ The Charter is the most advanced human rights instrument regarding the use of languages. Of course, mostly is important to minority languages, but also to other regional languages, something that helps us avoid the debate whether a certain group is a minority or not. It simply applies to languages that are different from the official language(s) of the state and are traditionally used in a given territory of a state by nationals of that state who form a group smaller than the rest of the population. ${ }^{12}$

Similar to the Framework Convention, the Charter is without prejudice to more favorable provisions in a state party concerning the status of languages, that exist whether in the domestic legislation or derive from bilateral or multilateral treaties. ${ }^{13}$

As to the content, the Charter sets out a number of measures to promote the use of regional or minority languages in public life (Part III of the Charter), especially in education, justice, administrative authorities, media, culture, economic and social activities. The state parties are obliged to apply minimum of 35 paragraphs or sub-paragraphs chosen from among the provisions of Part III of the Charter, in respect of the languages specified by the party at time of the ratification, acceptance or approval. ${ }^{14}$

10 European Charter for Regional or Minority Languages, Strasbourg, 05/11/1992, ETS no. 148.

11 For the list of state parties, see the official web site of the Council of Europe, http:/www.coe.int/en/web/conventions/full-list/-/conventions/treaty/148/signatures [last visited 04 October 2017].

12 In its Article 1, the Charter defines minority or regional language as a language that is (1) "traditionally used within a given territory of a State by nationals of that State who form a group numerically smaller than the rest of the State's population"; and (2) "is different from the official language(s) of that state".

13 European Charter for Regional or Minority Languages, Article 4.

${ }^{14}$ European Charter for Regional or Minority Languages, Article 2, paragraph 2. 
Regarding the use of languages in education, the Charter sets up a (possible) obligation for the parties to make available preschool, primary, secondary and university and higher education in regional or minority languages. ${ }^{15}$

Regarding the judicial authorities, the Charter stipulates a (possible) obligation of the parties to provide that courts, at the request of the parties, to conduct the proceedings in the regional or minority languages in criminal, civil and administrative matters. ${ }^{16}$

Regarding administrative authorities and public services, the Charter requires the (1) state administrative authorities, (2) local and regional administrative authorities, as well as (3) bodies providing public services, no matter public or private if they remain under public control (postal services, hospitals, electricity, transport and so on), (a) use the regional or minority languages; (b) make sure that their officers in contact with the public use the regional or minority languages; (c) to ensure users of these languages submit their applications and receive a replay in these languages. ${ }^{17}$

As for the media, the Charter requires state parties to ensure the creation of at least one radio station and one television channel in the regional or minority languages; to encourage and/or facilitate the creation and/or maintenance of at least one newspaper in the regional or minority languages; to support the training of journalists and other staff for media using regional or minority languages. ${ }^{18}$ The Charter also requires state parties "to guarantee freedom of direct reception of radio and television broadcasts from neighboring countries in a language is used in identical or similar form to a regional or minority language, and not to oppose the retransmission of radio and television broadcasts from neighboring countries in such a language. ${ }^{19}$

In the economic and social life, the Charter requires state parties, in the whole country: (a) to eliminate provisions that prohibit or limit without justifiable reasons the use of regional or minority languages in documents relating to economic life, such as contracts of employment, or technical documents such as instructions how to use products; (b) to prohibit provisions and clauses in internal documents of companies that exclude or restrict the use of regional or minority languages, at least between users of the same language; (c) to oppose practices that discourage the use of regional or minority languages. ${ }^{20} \mathrm{With}$ regard economic and social activities, the Charter requires by state parties to include in the financial and banking regulations provisions that will allow the use of regional or minority languages in payment orders (cheques, drafts etc.) or other financial documents. ${ }^{21}$

With these provisions, The Charter is the most advanced international instrument regarding the use of languages. It sets up very advanced status to regional and minority languages and creates clear rules in what fields and under what conditions users of regional and minority languages can use those languages, especially in public life. As international instrument, the Charter is very relevant to Macedonia, although Macedonia has not ratified it yet, even 21 years after its signing. The Charter is an instrument to be referred to, when we speak on the status of Albanian language in Macedonia, since the Charter also creates a certain status of regional or minority languages that is very close to what status has the Albanian language in Macedonia. So, there is a great argument that in

15 European Charter for Regional or Minority Languages, Article 8.

16 European Charter for Regional or Minority Languages, Article 9.

17 European Charter for Regional or Minority Languages, Article 10.

18 European Charter for Regional or Minority Languages, Article 11, paragraph 1.

19 European Charter for Regional or Minority Languages, Article 11, paragraph 2.

20 European Charter for Regional or Minority Languages, Article 13, paragraph 1.

${ }^{21}$ European Charter for Regional or Minority Languages, Article 11, paragraph 2(a). 
international law there is a standard on the use of languages that supports the status of the Albanian language in Macedonia.

\section{The legal framework in Macedonia regarding the use of languages, with special focus on the Albanian language}

In the next part, we will discuss the legal framework in Macedonia regarding the use of languages, starting from the Constitution and its Amendment V, the existing law and the new proposed draft law. This framework will be placed in correlation with international standards on the use of languages, as well as comparable national legislations.

\section{The Constitution and its Amendment V}

The Constitution of the Republic of Macedonia is adopted in 1991. In its Article 7 it stipulated that the only official language in whole country is the Macedonian language, while the language of a nationality is official language only in the units of the self-government (municipalities), where the majority or a considerable number of inhabitants live there, belong to that nationality, and how it can be used is determined by law. ${ }^{22}$

This Article was changed in 2001 with Amendment V to the Constitution ${ }^{23}$. According to this Amendment, the official language (1) throughout the country and (2) in its international relations is the Macedonian language and its Cyrillic alphabet. Additionally, "other language spoken by at least 20 percent of the citizens is also an official language and its alphabet, as specified with this Article". Thus, the Amendment V changes the approach of the Constitution of 1991 since allows another language and its alphabet to be an official language in the whole country.

Additionally, Amendment V sets up the framework for the use of the other official language that is spoken by at least 20 percent of the citizens: "(1) Any official personal documents of citizens speaking an official language other than Macedonian shall also be issued in that language, in addition to the Macedonian language, in accordance with the law; (2) any person living in a unit of local self-government in which at least 20 percent of the population speaks an official language other than Macedonian may use that official language to communicate with the regional office of the central government with responsibility for that municipality; such an office shall reply in that language in addition to Macedonian; (3) any person may use any official language to communicate with a main office of the central government, which shall reply in that language in addition to Macedonian; (4) in the organs of the Republic of Macedonia, any official language other than Macedonian may be used in accordance with the law;(5) in the units of local self-government where at least 20 percent of the population speaks a particular language, that language and its alphabet shall be used as an official language in addition to the Macedonian language and the Cyrillic

22 Constitution of Republic of Macedonia, Official gazette of Republic of Macedonia No. 52/1991 from 22 November 1991, Article 7.

23 Amendment V to the Constitution of Republic of Macedonia Official gazette of Republic of Macedonia No. 91/01. 
alphabet. With respect to languages spoken by less than 20 percent of the population of a unit of local self-government, the local authorities shall decide on their use in public bodies". ${ }^{24}$

With this framework, Amendment V allows the other official language to be used (1) in personal documents, in accordance with the law; (2) in the units of local self-government, as official language; (3) in the communication of the citizens with regional office of the central government, but located in a unit of the self-government; (4) in the communication with the main office of the central government; and most importantly, (5) in the organs of the Republic of Macedonia, in accordance with the law.

Thus, as a conclusion, the Amendment $\mathrm{V}$ prescribes that the Albanian Language is an official language in Macedonia since it is spoken by more than 20 percent of its citizens. Second, the Albanian language is an official language, but not of the same level of application as the Macedonian since, at least in international relations, the only language in use is Macedonian language. So that Albanian language is of the same level of application as the Macedonian, the Constitution should be changed and to provide that "in Macedonia there are two official languages, Albanian and Macedonian", as it is in the Constitution of Republic of Kosovo.25 As long as this doesn't happen, the Albanian language will not be of the same level of application as Macedonian. Thirdly, the Constitution, or more specifically Amendment V, demand adoption of a specific law for the use of the language that is spoken by at least 20 percent of the citizens. Of course, since the Constitution is a general act, the law is supposed to specify in details the application of the Albanian language as an official language in Macedonia. The law in force was adopted in 2008, 7 years after the adoption of Amendment V.

\section{The Law on the use of the language spoken by at least $20 \%$ of the citizens of Republic of Macedonia and in the unites of the local self-government ${ }^{26}$}

The Law on the use of the language spoken by at least $20 \%$ of the citizens of Republic of Macedonia and in the unites of the local self-government [hereinafter "The law on the use of Albanian language"] is the first law ever to regulate the use of Albanian language in Macedonia, adopted in 2008. The law was adopted based on the provisions of Amendment V of the Constitution that require the adoption of such a law. As such, this law doesn't specify that it is dedicated to Albanian language, but repeats that its dedicated to language that is spoken by $20 \%$ of the citizens. The law is still in force, with great possibility to be changed by the new draft-law that is already in e parliamentary procedure.

The law on the use of Albanian language of 2008 has two determinant specifics. (1) The first one is that it doesn't not make the Albanian language official language in the institutions. Rather, it creates an individual right for persons to use the Albanian language in certain institutions or in communication with the institution. Only in the units of the self-government where at least $20 \%$ of

24 Amendment $\mathrm{V}$ to the Constitution of Republic of Macedonia.

${ }^{25}$ The Constitution of the Republic of Kosovo, in its Article 5 titled "Languages" provides that "Official languages in the Republic of Kosovo are the Albanian language and Serbian language". The Constitution of Kosovo available at www.rks-gov.net [last visited 07 October 2017].

${ }^{26}$ The Law on the use of the language spoken by at least $20 \%$ of the citizens of Republic of Macedonia and in the unites of the local self-government, Official gazette of Republic of Macedonia No. 101/08 from 13.08.2008. 
the citizens are Albanians, the Albanian language is official in that unit. ${ }^{27}(2)$ Second, the Law on the use of Albanian language of 2008 specifies when the Albanian language is used, in which way actually at the same time prohibits its use outside the framework that it creates. So, the law has two sides, on one side allows the use of Albanian language, but at the same time restricts its use outside its scope. For example, since the law does not provide the use of Albanian language in the Government of the Republic of Macedonia, the ministers that speak Albanian do not have the right to speak in the Government's sessions or its bodies in Albanian. So the law actually restricts the right to use Albanian language in this specific case.

As to its scope, members of the Parliament that speak Albanian have the right to use the Albanian language in the Parliament's sessions, in the parliamentary commissions, or to get the materials in Albanian. ${ }^{28}$ But the official language of documents and other acts of the Parliament remained Macedonian.

Similarly, citizens that live in a unit of the self-government where $20 \%$ speak Albanian, can address (communicate with) the regional offices of the ministries in that unit in Albanian language. The office will answer in Macedonian and Albanian, ${ }^{29}$ but the official language in the institutions remains Macedonian language. Citizens that live in a unit of the self-government where at least 20\% speak Albanian, can address (communicate with) the ministries (main offices) in Albanian. The ministries will answer in Macedonian and Albanian, but the official language in the Ministries remains Macedonian language. ${ }^{30}$

In the judicial proceedings (criminal, civil or administrative), the parties (the accused, the damaged, plaintiffs, defendants, witnesses and others) that speak Albanian, can use this language when they address the courts, they can ask the materials in Albanian, they can submit a request or a motion in Albanian language. Also they can ask the judgment to be translated in Albanian and to submit the appeal in Albanian. They also can ask for a translator, that is free. ${ }^{31}$ But however, the official language for the procedure remains the Macedonian language. Thus, there have been situations when the judge, the persecutor and the accused are all Albanians, but he official language in the procedure remains Macedonian language.

The law on the use of Albanian language of 2008 allows the use of Albanian language in the education process, in the media, in the personal documents, in the electoral process and similar. But, the main critique of The law on use of Albanian language of 2008 remains that it does not recognize the Albanian language as an official language within the institutions (especially those of the central government), but only creates an individual right the language to be used by the citizen. Having this approach, the law of 2008 grants even a lower standard that the European Charter for regional and minority languages sets up. Namely, in Article 10 the Charter requires from state parties to ensure the administrative authorities (of the central government), local and regional authorities, and even persons providing public services, to use the regional or minority language, besides the right of the

27 The Law on the use of the language spoken by at least $20 \%$ of the citizens of Republic of Macedonia and in the unites of the local self-government, Article 41-43.

28 The Law on the use of the language spoken by at least $20 \%$ of the citizens of Republic of Macedonia and in the unites of the local self-government, Article 3.

${ }^{29}$ The Law on the use of the language spoken by at least $20 \%$ of the citizens of Republic of Macedonia and in the unites of the local self-government, Article 4, paragraph 1 and 2.

${ }^{30}$ The Law on the use of the language spoken by at least $20 \%$ of the citizens of Republic of Macedonia and in the unites of the local self-government, Article 4, paragraph 3 and 4.

${ }^{31}$ The Law on the use of the language spoken by at least $20 \%$ of the citizens of Republic of Macedonia and in the unites of the local self-government, Articles 5-19. 
person to use such a language. 32 Also this law is of a lower standard with the law of Kosovo that provides that in all levels, there are two official languages with equal status, the Albanian language and the Serbian language.33For this determinant reason, the new draft law is of important relevance.

\section{The New Draft-Law on the use of languages ${ }^{34}$}

The New Draft-Law on the use of languages is in a parliamentary procedure. The parliament will continue its session after the local elections in 12 October 2017. The New Draft-Law will probably be adopted at the end of October or beginning of November 2017. With its adoption, the actual Law of 2008 will be replaced and its application will be discontinued. ${ }^{35}$

First of all, although symbolical, still important, the New Draft-Law expressly specifies that the language spoken by at least $20 \%$ of the citizens is the Albanian language. ${ }^{36}$

Second, as it was mentioned, the New Draft-Law on the use of languages changes the approach towards the Albanian language and from an individual right, it provides that will be an official language in the institutions of the state. Article 1 paragraph 3 provides that "in all organs of the state in the Republic of Macedonia, central institutions, public enterprises, agencies, directorates, establishments and institutions, commissions, public bodies that provide public services according to the law, as well as other institutions, official language besides Macedonian and its alphabet, is the language spoken by at least $20 \%$ of citizens in the Republic of Macedonia and its alphabet" ${ }^{37}$ Similar, in Article 2, paragraph 3, the new Draft Law repeats that in the same institutions enumerated just earlier, official language is the Albanian language as well, (1) in the communication, (2) use and (3) application in all the procedures of the citizens before these institutions (the Parliament, Government, judiciary, public prosecution, Constitutional Court, Ombudsman, in the electoral process, education, science, health, culture, police authorities, personal documents, finance, public notary, media etc.).

According to this approach, in the Parliament and in the Government, the new Draft Law provides that besides Macedonian, official language is the Albanian as well. ${ }^{38}$ So, in these two institutions, both languages are of an equal status.

The third specific of the New Draft-Law on the use of languages, that is related to the second, is that allows very broad application of the Albanian language in the procedures of the institutions. Thus, in the procedures in front of all the organs and institutions, including judicial institutions, the procedure will be in Albanian if only one party or participant in the procedures is Albanian.

32 See supra, foot note 17 and accompanying text.

33 The Law on the use of languages (Law no. 02/L-37 of 27 July 2006, available at www.komisioneri-ks.org [last visited 7 October 2017]) in its Article 2 paragraph 1 stipulates that "Albanian language and Serbian language and their alphabets are official languages in Kosovo and have equal status in Kosovo's institutions".

34 Draft-Law on the use of languages, available at www.sobranie.mk [last visited 8 October 2017] [hereinafter "The New Draft-Law on the use of languages"].

35 The New Draft-Law on the use of languages, Article 24.

36 The New Draft-Law on the use of languages, Article 1, paragraph 2.

${ }^{37}$ The New Draft-Law on the use of languages, Article 1, paragraph 3.

38 The New Draft-Law on the use of languages, Article 4, paragraph 1 and Article 5, paragraph 1. 
Respectively, all decisions and other acts in these procedures have to be in Albanian too. ${ }^{39}$ This approach improves the defect of the existing law which didn't allow the procedure as such to be in Albanian even if the judge, the prosecutor and the lawyers were Albanians. It only allowed the parties to use the Albanian language (as an individual right), but not the procedure as such to be held in Albanian.

Lastly, the scope of the new Draft-Law is very broader since it requires the use of Albanian language in some areas that were not covered until now. Thus, the names of the institutions with seat in the units where $20 \%$ are Albanians, to be writtenin Albanian; ${ }^{40}$ the web pages of the institutions to be in Albanian as well $;{ }^{41}$ the money bills and coins to contain symbols that will reflect the cultural inheritance of Albanianstoo; ${ }^{42}$ the uniforms of policemen, firefighters, medical personnel in unites of the self-government to be in the language spoken by at least $20 \%$ of the citizens in that unit; ${ }^{43}$ names of streets, bridges, boulevards, squares and other infrastructural objects in all units of the local-self-government where at least $20 \%$ of the citizens speak other language than Macedonian, will be written in that language too. ${ }^{44}$

The New Draft-Law requires the establishment of two new institutions competent to follow the implementation of this Law, namely the Agency for the application of the language spoken by at least $20 \%$ of the citizens in Republic of Macedonia ${ }^{45}$ and Inspectorate for the use of languages. ${ }^{46}$

\section{Conclusion}

The New Draft-Law on the use of languages is expected to advance the use of the Albanian language in Macedonia and to remove some defects that were detected. It is very important that in some parts, the New Draft-Law makes Albanian language equal to Macedonian. It also makes Albanian language an official language in institutions in which the procedures will be held. This law is in accordance with the Constitution of the country, since the Constitution in its Amendment V requires adoption of such a law. Also, the New Draft-Law is in accordance with international standards on use of languages, especially the European Charter for regional or minority languages. For this reason, it is recommended that Macedonia ratifies this Charter, a move that will be in a coordination with the adoption of the New-Draft Law.

\footnotetext{
${ }^{39}$ The New Draft-Law on the use of languages, Article 6, paragraph 1 and 2; Article 9, paragraph 1.

${ }^{40}$ The New Draft-Law on the use of languages, Article 7, paragraph 7.

41 The New Draft-Law on the use of languages, Article 6, paragraph 4.

${ }^{42}$ The New Draft-Law on the use of languages, Article 8, paragraph 1.

${ }^{43}$ The New Draft-Law on the use of languages, Article 8, paragraph 3.

${ }^{44}$ The New Draft-Law on the use of languages, Article 16.

${ }^{45}$ The New Draft-Law on the use of languages, Article 18.

${ }^{46}$ The New Draft-Law on the use of languages, Article 20.
} 


\section{References}

1. European Charter for Regional or Minority Languages, Strasbourg, 05/11/1992, ETS no 148 ;

2. Framework Convention for the Protection of National Minorities, Strasbourg, 1/2/1995, ETS 157;

3. The Declaration on the Rights of Persons belonging to National or Ethnic, Religious and Linguistic Minorities was adopted by the UN General Assembly Resolution 47/135 of 18 December 1992;

4. The Law on the use of languages in the Republic of Kosovo (Law no. 02/L-37 of 27 July 2006);

5. The Law on the use of the language spoken by at least $20 \%$ of the citizens of Republic of Macedonia and in the unites of the local self-government, Official gazette of Republic of Macedonia No. 101/08;

6. The New Draft Law on the use of languages, available at www.sobranie.mk; 